\title{
Aphorisms with an Opening (and Closure) Effect
}

Aforismos con un efecto de apertura (y un efecto de clausura)

Marco Aurelio Ángel-Lara

Universidad Autónoma de Querétaro (México)

Received: 2014-09-05

Sent for peer review: 2014-09-06

Approved by peers: 2014-12-10

Accepted: 2014-12-17

Pensamiento y Cultura | ISSN: 0123-0999 | eISSN: 2027-5331

pensam.cult | Vol. 18-1 | Junio de 2015 | pp. 76-106

DOI: 10.5294/pecu.2015.18.1.3 


\title{
Aphorisms with an Opening (and Closure) Effect
}

\begin{abstract}
The article introduces a distinction to de-simplify the common view of aphoristic texts that produce a reading experience of apparent disproportion between the size of the text and its meaning. The question is how that reading effect is generated and what aphoristic techniques can be employed. The author believes a more complex awareness will lead not only to a finer critical sense of the genre, but also to an understanding of creative aphoristic techniques. The scope of the article is limited to several aphoristic texts, specifically ones that are read most frequently and definitely preferred in our current society. Two categories are coined for them: aphorisms with a closure effect and aphorisms with an opening effect.
\end{abstract}

Keywords: aphorisms; taxonomy; meaning; literature; philosophy.

\section{Aforismos con un efecto de apertura (y un efecto de clausura)}

Resumen: el artículo propone una distinción que de-simplifica la opinión común sobre algunos textos aforísticos -aquellos que producen la experiencia lectora de una desproporción entre extensión y significado-. La cuestión es cómo son producidos ciertos efectos de lectura y qué técnicas aforísticas se emplean para el caso. Un entendimiento más sutil de la cuestión llevará a una mejor inteligencia crítica sobre el género y, asimismo, a una comprensión mayor de la técnica de la creación de aforismos. El foco temático del artículo se limita a ciertos textos aforísticos, aquellos que son más leídos en nuestra época actual, acuñando para ellos dos categorías: aforismos de efecto de clausura y aforismos de efecto de apertura.

Palabras clave: Aforismos; taxonomía; significado; literatura; filosofía.

\section{Introduction}

Many readers highlight the 'power' of aphorisms to produce the reading effect of an apparent disproportion between textual size and meaning as a characteristic feature of the genre. I have suggested the emphasis that some contemporary critics have placed on this experience when charac- 
terizing aphorisms speaks to the readers' subjectivity as much as to the texts themselves (Angel-Lara, 2013). This focus of attention seems to be telling us something important about the expectations, interests and preferences of contemporary reader and, of course, of writers who share a generic channel of communication with them. However, despite the attention this effect has attracted, there does not seem to be a proper analysis of it, as a significant feature of current aphorisms. Furthermore, attempts to simply reduce the entire group of generic texts to this effect are commonplace.

In what follows, I speculate on several characteristics of aphoristic texts that produce the experience of an apparent disproportion between textual size and meaning, so as to introduce a distinction to de-simplify the common view of that reading effect. I believe a more complex awareness can lead not only to a finer critical sense of the genre, but also to an understanding of creative aphoristic techniques. The scope of the article is limited to certain aphoristic texts that are read most frequently and certainly preferred in our current society. I introduce two categories for them: aphorisms with a closure effect and aphorisms with an opening effect. First, I describe the aphoristic closure effect, illustrate it and suggest that its relatively current abundance blurs the common understanding of the genre. Secondly, and more extensively, I explore the opening effect of aphorisms by providing some examples, reviewing some of the mechanisms and proposing some ideas on its general functioning.

\section{Aphorisms with a Closure Effect}

Texts of the aphoristic genre are commonly thought of as statements in the face of which there seems to be nothing more to argue. Such an impression of the nature of aphorisms is illustrated by an extract from the article "On the Difficult Art of Aphorism" by James Fenton:

Sontag, when writing about Roland Barthes, said: "It is in the nature of aphoristic thinking to be always in a state of concluding; a bid to have the final word is inherent in all powerful phrase-making." [...] 
Whatever meanings we come up with, a successful aphorism has this power to provoke an interpretation, and to force our assent. (Fenton, 2007: 15. My emphases)

In Fenton's account, aphorisms appear to be the conclusion of a communicative exchange by producing a forced agreement. It would be interesting to know to what extent a perspective like Fenton's was shared by Auden and Louis Kronenberger when imagining the aphorist's attitude:

The aphorist does not argue or explain, he asserts; and implicit in his assertion is a conviction that he is wiser or more intelligent than his readers. For this reason the aphorist who adopts a folksy style with 'democratic' diction and grammar is a cowardly and insufferable hypocrite. (Auden, 1964: vii-viii)

Aphoristic assertions may appear to foreclose the possibility that there is anything worth adding. Clifton Fadiman, however, analyses this in a subtly different way compared to Auden and Kronenberger: it is not that the aphorist believes his intelligence superior to his readers', but rather that the readers in fact share such an attitude with the aphorist:

The statements of the classical aphorist are not issued from a position of danger. Indeed that is why we enjoy them; both aphorist and reader occupy for an instant the safe perch of superiority. (Fadiman, 1962: 21)

In somehow less hard terms, Susan Sontag says: "Aphoristic thinking is informal, unsociable, adversarial, proudly selfish." (1980: 191). Whatever the case, it is clear that an attitude is commonly attributed to users of this kind of written text. However, if one assumes that aphorisms are a complex genre (within which other kinds of aphorisms such as legal and medical texts are included), one might wonder why they have been associated mainly with this attitude. One might be tempted to think that the importance La Rochefoucauld's work to the development of the modern 
aphoristic tradition may explain the origin of this widespread belief. ${ }^{1}$ In any case, many of La Rochefoucauld's texts embody such ideas about the genre, making it worthwhile to look at some in relation to such beliefs.

It is clear that although texts contained in La Rochefoucauld's Réflexions ou sentences et maximes morales are endowed with an apparent objectivity (which can be easily seen as a ruthless insight as well), they also provide a subjective (and persuasive) view of life according to which the world we inhabit is essentially worse than it seems (there are no good and disinterested actions, because self-love is the source of all human behaviour). From the epigraph onwards, La Rochefoucauld's view of human behaviour and motives strikes the reader:

- Nous vertus ne sont, le plus souvent, que des vices déguisés.

- Our virtues are most frequently but vices in disguise. (2001:3)

This perspective is sustained throughout the book. Here are but a few examples:

1. Ce que nous prenons pour des vertus n'est souvent qu'un assemblage de diverses actions et de divers intérêts, que la fortune ou notre industrie savent arranger; et ce nest pas toujours par valeur et par chasteté que les hommes sont vaillants, et que les femmes sont chastes.

What we take for virtues are often only a collection of various actions and interests that fortune or our own industry knows how to arrange; and it is not always through valor and chastity that men are valiant and that women are chaste. (2001:3)

2. Lamour prope est le plus grand de tous les flatteurs.

Self-love is the greatest of all flatterers. (3)

1 For instance, Melvin Maddocks writes: "La Rochefoucauld is considered the father of the aphorism, giving the literary form a record of over three hundred years". (2001: 171) 
122. Si nous résistons à nos passions, c’est plus par leur faiblesse que par notre force.

If we resist our passions, it is more through their weakness than through our strength. (25)

\section{L'hypocrisie est un hommage que le vice rend à la vertu.}

Hypocrisy is homage vice pays to virtue. (43)

Readers' reactions to the Maxims have not usually been as detached as the seemingly dispassionate tone of the book itself, but perhaps more akin to the shock of a slap in the face: "When Madame de La Fayette, later the tender companion of his old age [La Rochefoucauld's] and author of the first modern French novel, La Princesse de Clèves, first read the Maxims, she exclaimed, 'Ah, what corruption of mind and heart one must have to be able to imagine all that!'” (Dalrymple, 2001). It seems that such an emotional response to the Maxims as this one has been common over the years and is well acknowledged by scholarly critics of La Rochefoucauld:

The more poignant, paradoxical maxims also tend to elicit, at least from many readers, an intuitive or emotive response, an immediate reaction to which notions of the maxim's impact or effect have [been] commonly linked. Pagliaro refers forthrightly to "nervous response, and the disturbance that precedes cognition"; other critics prefer metaphorical allusions to the wounds inflicted upon the reader's spirit, or to the feeling of moral paralysis engendered by the Maximes. It is clear, in any case, that the initial bite of the maxim increases both the difficulty of and the necessity for intellectual detachment. (Lewis, 1977: 42. My emphases)

I believe this emotionally provocative quality - this 'slap in the face' - is generally associated with aphorisms.

One finds similarities, to some degree, when comparing reactions to La Rochefoucauld's Maxims to a general statement about the genre of aphorisms. James Geary writes: "Aphorisms aren't meant to make 
you feel good about yourself [...]. Aphorisms deliver the short sharp shock of an old forgotten truth." (2005: 8). Geary keeps going: "Aphorisms are not the warm and fuzzy phrases found in greeting cards. They are much more brusque, confrontational, and subversive. You don't curl up with a good book of aphorisms; they leap off the page and unfurl inside you." (2005: 7).

It is not unreasonable to think the "sharp shock of an old forgotten truth" mentioned by Geary somehow refers to the power that "forces our assent," as pointed out above by Fenton (2007: 15). That forced assent, or that sharp shock, might be the subject of the Sontag text: "It is in the nature of aphoristic thinking to be always in a state of concluding; a bid to have the final word is inherent in all powerful phrase-making." (Fenton, 2007: 15)

From Sontag and Fenton's perspective, aphorisms provide a sense of closure, much like the word that concludes a line of thought or an argument. This may be what Pagliaro refers to when he says:

Despite its power to induce the shock of recognition, the aphorism can be a misleading teacher, simply for the reason that all its paradoxically energized circuits are closed systems. (Pagliaro, 1964: 50)

In recognition of this property of the reading of aphorisms, I will refer to the impression produced by certain aphoristic texts of being "always in a state of concluding" as the closure effect.

It is important to mention that the closure effect could be easily confused with the shock effect produced by many aphorisms, conspicuously those of La Rochefoucauld. It may be that, by seeing aphorisms mainly as conclusive statements, one may be tempted to think this kind of lapidary text to which the reader has nothing more to add is a dead end of the circuit of communication. At this point, I would like to draw attention to the fact that the mere use of a funerary metaphor such as 'dead end of the circuit of communication' might contribute to the confusion between a closure effect and a shock effect, fusing these elements through a familiar conception of death: as a conclusion (of life) and as a metonymy of the emotional 
shock that death produces in us. It should be noted that my example is not gratuitous. Funerary metaphors are not unusual when talking about aphorisms and constitute fertile ground for confusion between the effects of closure and shock (my italics):

In the lyric poem, aphorism functions very much as Bacon suggests, producing a lapidary effect (Lindley, 1986: 57)

All learning worth the name involves the murder of an old idea by a new one. Paradoxical aphorisms are among the beneficent executioners of decrepit ideas, and they do their work in a handful of orderly ways. (Pagliaro, 1964: 50)

By virtue of its brevity and lapidary precision, Nietzsche's aphoristic style constitutes a particular provocation to the reader. (Marsden, 2006: 30)

The aphorism says the truth in the form of the last judgement, and this truth carries death. (Derrida, 1992: 418)

E. P. Lewis, supporting the idea that the maxim is "conclusion without introduction," quotes Roland Barthes:

(The maxim) is immediately, in its entirety, in its heart, in its very death, since one grasps in a single movement its beginning and its ending. (Lewis, 1997: 25. His italics, bold mine)

In summary, there are two different elements I would like to distinguish here: a certain sense of concluding and an emotive reaction. ${ }^{2}$ Although it is not difficult to conceptualize these elements separately,

2 Once these two elements have been distinguished, I would just like to point to this sense of concluding effect. Describing some aphorisms as a kind of conclusion implies the existence of a previous part of which they act as the final statement. Here, the question would be: what discourse is previous to the aphoristic text? I believe the answer points to discourses related to the context that aphoristic texts access to make full sense., See Ángel-Lara 2011-b. 
it is easy to forget that concluding and shocking are not synonyms, thinking that all aphoristic texts are aphorisms of both $a$ closure and $a$ shocking effect. Nonetheless, that is not the case. To illustrate my point, I would like to consider Joubert's text:

Adressez-vous aux jeunes hommes, ils savent tout. (1989: 41)

[Ask the youngsters, they know everything.]

The text refers to youth's arrogance with a seemingly benevolent irony. The text conclusively makes its point, departing from a well-established commonplace about the attitude of young people. It strives for persuasion, not for validity. Within the context of an argument, the text must be taken as a fallacy (as an attack ad hominem or as a Petitio Principii). In this sense, its functionality depends on stopping a reply. On the other hand, one can see its point is made in a manner that produces more of a smile than a shock; thus, not all conclusions shock. What is more, the final attitude of the aphorist, though perhaps a little bitter, does not seem to be arrogant -this is, then, just one counterexample that troubles simplistic beliefs that the genre is constituted only by shocking-authoritative-conclusive texts.

\section{Proposing a New Category: Aphorisms with an Opening Effect}

Not all aphorisms can be classified as texts with a closure effect. The reading of certain aphorisms produces, so to speak, a very different aftertaste than a sharp shock. There is a rarer reading effect, which is scattered within the aphoristic tradition and for which I have a personal preference -particularly with regards to its smoother quality. I would like to add a category to this way of talking about aphoristic texts: the aphorisms with an opening effect. So rare might be the opening aphoristic effect that one of the 'laws' James Geary prescribes for the genre would exclude its possible existence: "It [the aphorism] Must Be Definitive" 
(2005: 12). ${ }^{3}$ In opposition to Geary, I would like to argue that the opening effect exists and it has, to an extent, already been acknowledged. I also will illustrate it by presenting some aphoristic texts that can produce it.

In his article "The Aphorism as a Stylistic and Epistemological Ideal," Josef Fruchtl writes:

The aphoristic is a mode of writing that further propels the stream of ideas not so much by standard argumentative or even logically deductive connections, but by brief and pointed, yet not necessarily generally understandable or easily remembered judgements -by aphoristic sentences. (Fruchtl, 1997: 171. My emphasis)

For the sake of argument, one could assume Fruchtl and Fenton would agree to a certain extent about the language of aphorisms. It would not be unreasonable to take Fruchtl's "brief and pointed [...] judgements" as an alternative account of the "powerful phrase-making" described above by Fenton. However, this hypothetical agreement on the sort of language we are dealing with would contrast with the outcomes that Fruchtl and Fenton have recognized. The coercive power that forces our assent, pointed out by Fenton, can be contrasted with the impelling power for the production of ideas, noted by Fruchtl. On the one hand, aphorisms seem to finish an argumentative chain or a stream of ideas by becoming the last word -they are a closure to something. On the other, aphorisms seem to start an intellectual movement, being an active force by provoking more thought -they appear as the beginning of an intellectual action, as an opening.

3 "It Must Be Definitive. [...] a definition -like an aphorism- must be, well, definitive. [...] an aphorism is something that marks off or sets apart; that is, a definition.

Aphorisms and definitions assert rather than argue, proclaim rather than persuade, state rather than suggest. [...]

Because aphorisms must tell, at once, they often take the form of definitions $-\mathrm{x}$ is $\mathrm{y}$. There is no deliberation or debate, and no supporting evidence. We must literally take the aphorist at his word. That's usually easy enough, because those words are so lucid they compel their own conviction. [...] aphorists are far from harmless. They are troublemakers and iconoclasts, dogmatists whose majestic authority commands consent. They are, by definition, revolutionaries who hold their truths to be self-evident." (Geary, 2005: 12-13) 
I could not tell if, in the following quotation, Gary Saul Morson is referring to what I call an opening effect, but what is certain is that his words do not apply, by any means, to a sense of concluding, as described by Sontag and Fenton: "An aphorism does not coincide with itself. The formula of identity, $A^{\star} A$, does not apply to it. It is perpetually unfinished, always reaching beyond itself. When we enter it, we intimate a wholly different world." (Morson, 2003: 429) It is pertinent to add that an opposition between the closure effect and opening effect does not necessarily imply an exclusion of one by the other. It could be said that this terminology applies, in the case of the closure effect, to the first reading reaction. In the case of an aphorism with an opening effect, one would say that quite often the first reading reaction is to be puzzled, then to wonder about that puzzlement and then, perhaps, to feel like opening something. Nonetheless, it is important to add that a closure effect -or a slap in the face- sometimes acts as an awakening that opens other ways of seeing. Moreover, this terminology is not an attempt to reduce the complexity of subjective (aesthetic) experiences to a conceptual map; its first aim is to avoid simplistic views on the effects that aphorisms can achieve.

Consider the next text:

Of those who remember their childhood and those who only remember school. ${ }^{4}$

(Joubert, 1983: 103)

In this case, the text seems to strive for completion but not for sense. Its grammatical incompleteness invites us to wonder: Who is it talking about? What are they like? Which would I belong to? The text only points to something. It indicates a subject, signalling a single feature of two potential characters. By being together in the text, these features seem to throw light on each other, suggesting their possible characters. A careful touch can be seen as well: there is no complement; nothing explicitly shows any relation between such possible characters. However, seemingly it is precisely this 'gap' that compels us to imagine any possibilities

4 Due to logistic impediments, I could not count on the French text. 
that would complete the text. Such a gap is suggestive enough to invite not only one question but several, and there is no given answer for any of them.

I also think the following aphoristic texts are examples of the opening effect:

(1) ¡Ah! ¡Si pudiéramos arrepentirnos antes!

[Ah! If we could regret beforehand!]

(2) Tú crees que me matas. Yo creo que te suicidas.

You think you are killing me. I think you are committing suicide.

(3) Convictions are more dangerous enemies of truth than lies.

They all somehow disturb our normal way of seeing things: first, by an adverb misplaced; next by the open-ended transitiveness of an action and, finally, by the subversion of the common-place opposition between the truth and a lie. The first text troubles temporal order expectations, the second raises an issue of (human) identity and the third points at a conceptual complication of a common idea of truth. By doing what is not completely obvious, each aphorism can prompt us to rethink or to wonder about something that is beyond the text itself.

The first and second texts are by the Argentinean writers José Narosky (1975: 111) and Antonio Porchia (2003: 22-23), respectively, and the last one is by Nietzsche (1993: 35). I have also removed the author's name from the next two texts to present them, in a list with the previous three, to some readers and to observe their reactions:

(4) The world is everything that is the case.

(5) Whereof one cannot speak, thereof one must be silent.

For those familiar with Wittgenstein's work (2003: 31 \& 189) and its significance to contemporary philosophy, it would be surprising to hear that readers with no awareness of current philosophical thinking 
did not seem to be affected as strongly by texts (4) and (5) as they were by texts (1), (2) and (3) -which were presented on the same page, also without the authors' names. However, this is not so strange, since the knowledge necessary to contextualize texts (4) and (5) "appropriately" can be classified as more specialized than the knowledge necessary to make sense of the three previous texts. We are used to thinking of Wittgenstein's texts within the contextual reference of his Tractatus; thus, leaving out the author's name significantly changes the texts' interpretation. It may be interesting to hear that some readers who have not read or did not recognize Wittgenstein's texts (or have no knowledge of them and/or of his work) interpreted his proposition "The world is everything that is the case" as something like "Sadness or happiness is related to the things that matter to me;" others also told me they did not understand text (4), but that it seemed to them to be a positive phrase. The second text, "Whereof one cannot speak, thereof one must be silent," appeared to most of these readers as merely an authoritarian piece of advice, a blatant assertion.

I believe all these aphorisms can produce an opening effect in a variety of ways. However, some texts seem to be designed to provide, within themselves, the necessary clues to connect with a vaster cultural frame of (unspecialized) information, while other texts belong to a specific context of references. In the case of the first three texts by Narosky, Porchia and Nietzsche, contexts are already in place within a culturally shared background; thus, these texts take advantage of issues related to our common conceptions of time, human beings and truth. To a certain degree, such use of the common cultural stock can be thought of as a feature that separates these three texts from the two by Wittgenstein. However, one must acknowledge this is a fuzzy distinction.

Another way of drawing this distinction between these aphorisms is by thinking about the intentions of their makers. In my opinion, one can assume that full time aphoristic writers, such as Porchia and Narosky and, frequently, Nietzsche, aimed to produce texts that could be read on their own, without requiring a surrounding text.

These kinds of texts have been identified, by some critics, as self-contained: 
Consider the critic's practice of calling certain prose style "aphoristic," by which he usually means a pithy, well-turned, and concise style. (Instances of muddle, where the word is identified with the "satirical," need not detain us.) Now, we assume that the aphorism is distinct and self-contained - that it is a prose genre of its own; and by 'self-contained" we mean nothing more mysterious than that, as it is printed on the page, it requires no further words, on that page, before or after it, to achieve its effect. (Stern, 1963: 194)

In contrast, many aphorisms from the Tractatus Logico-Philosophicus seem to show clearly that such an aim does not apprise Wittgenstein's writing practice, as can be observed in the following propositions:

2.131 The elements of the picture stand, in the picture, for the objects.

3.4 The proposition determines a place in logical space: the existence of this logical place is guaranteed by the existence of the constituent parts alone, by the existence of the significant proposition.

3.5 The applied, thought, propositional sign is the thought.

It can be added that, distinguishing between aphorisms (1), (2), (3) -as texts that rely on a culturally shared context- and aphorisms (4) and (5) -as texts that rely on a quite specialized context- separates texts in two categories, ${ }^{5}$ invalidating a homogeneous application of a value judgement. In other words, canon related issues should take into account this kind of separation.

5 In this sense, it could be argued that, in order to facilitate a meaningful context for aphoristic texts, it is easier to build upon bases that are already in place -as texts (1), (2) and (3) do- than to revolutionize philosophical thinking. Thus, it could be argued that this difficulty should be a criterion for rating the texts. Nonetheless, the point I want to make is that, from another perspective, texts can be seen as belonging to two different textual types, with different functions and, thus, different criteria. (I acknowledge the name of Nietzsche, among the first three authors, makes such an affirmation contentious; however, according to my survey, Nietzsche's text can, in fact, be understood without having a specialized academic background, when it appears edited, as it did here.) 
It should be noted that this way of distinguishing between texts (texts designed to use a shared background and texts not designed to do so) is also risky and will not escape from being accused of committing an intentional fallacy (because it only relies on conjecturing writers' aims from the way in which we read their texts). As such a distinction will be necessary for my argument, I cannot think of better evidence to offer than my own testimony -as the author of the aphoristic book $E l$ atril de la luciérnaga- for dealing with issues related to authorial intention: As an aphorist, I write aphorisms assuming a particular communicative exchange from which my texts will benefit: readers expect to make sense of texts without complementing them with more text, and I attempt to provide shared references for them to tease out information from a background they probably share with me. My writing intention is to design texts that fulfil such an expectation. ${ }^{6}$

\section{Some Aphorisms with an Opening Effects}

The type of opening effect for which I have a personal preference belongs to the first kind of aphoristic text; i. e., aphorisms that stand alone. The belief that another aphoristic effect -such as an 'opening effect' - is possible besides 'closure' has given me a helpful perspective: it has provided me with a wider frame of reference when studying critical essays on the genre -which are generally too focused on the closure effect- and has allowed me some general conjectures about such an effect. In what follows, I present a schematic classification to discuss the opening effect.

6 This is not the place to tackle the issue of intentionality, and I only highlight the problem for a further article (in which I may try, as some kind critics have suggested, to explore the relation between different aphoristic techniques and different types of meaning, reflecting on poetic image or, even, by applying reception theory). So, without further ado: Yes, it is very problematic to guess authorial intention from reading effects or, this being the case, from my own testimony as an author. However, if the reader bears with my argument despite this flaw, then I could offer some insights from my creative writing practice, which may feed the critical conversation on the genre. This being the aim, the reader will notice that, at this point of the article, I will leave the discussion on critical tradition to jump into another literary area: that of creative writing. 
Within aphorisms that have an opening effect, I have identified several subtypes that I would like to propose as a working arrangement towards a further classification. I will bring to this discussion several excerpts from The Lectern of a Firefly (2012) to exemplify a few recognizable patterns of texts with an opening effect. These texts were shown to a wide variety of readers (poets, prose writers, academics, friends and family) who have told me, or discussed with me, their reading experiences. ${ }^{7}$ My explanation will reduce the opening effects' machinery to some general features related to readers, texts-context and author intentional design.

As a writer of aphorisms, I assume readers use certain conventions such as, for instance, the notion that aphorisms are self-contained (see Stern's quotation) and aphorisms are philosophical (in the broad sense as discussed in Angel-Lara 2011b). I also expect readers will attempt to make sense of such texts (the convention would go something like this: aphoristic texts, no matter how obscure, can make sense). For me, the first convention is important because it ensures the reader will look only within the text to find the necessary clues to produce a plausible interpretation; $i$. e., the reader will not try to place the text within another written text to make sense. The second convention should lead the reader to the probable field of reference to contextualize the text. The latter belief ensures that readers will actively seek meaning, trusting that texts have been designed to produce it.

In general, I believe the last conviction ties the reader's expectations to an epistemic goal: to make sense of the aphorism. The aphorist can play this aim to his advantage. By suspending the fulfilment of such

7 Leaving aside the practical difficulty of finding aphorisms with an opening effect, my personal experience is the best evidence on which I can rely to corroborate an aphorist's intention, when talking about the means implemented to achieve writing aims. In other words (paraphrasing Wimsatt and Monroe, 1946), using my own work offers an assurance that the design and/or the intention of the author is available when judging the success of the means he has implemented in his attempts to produce an opening effect. Wimsatt and Monroe wrote in the same article:

In order to judge [a] poet's performance, we must know ' what he intended. Intention is a design or plan in the author's mind. Intention has obvious affinities for the author's attitude toward his work, the way he felt, what made him write. (1988: 314) 
an expectation, the writer destabilizes the reader's frame of mind and can use his impulse to find a balance for promoting the creation of interpretive possibilities for the text. Accordingly, it is the reader who proposes interpretations, playing an active role in the completion of the aphorism. This may be a way of saying the text is not given to him closed, but open. We could schematize this cycle as follows: postponed stability (text does not make explicit sense), reader struggles to resolve the instability (search for interpretation) and, finally, a new stability is found (the text makes sense by connecting meaningfully with the shared reference). In what follows, I will discuss several aphorisms I wrote when trying to produce such a cycle. I will propose some categories to distinguish different types of texts with an opening effect: I) Aphorisms that Trouble Common Sense, II) Aphorisms that Hint at a Character, III) Confessional Aphorisms, IV) Metaphorical Aphorisms, V) Aphorisms that Tease a Commonplace, VI) Aphorisms that Hint at Questions and VII) Aphorisms that Tease Out Cultural Assumptions. This is not an attempt to produce a generic taxonomy or, by any means, an exhaustive or a restrictive classification. The following is only an effort to reflect on the craft of aphoristic writing from a personal perspective, based on my experience.

4.1. I) Aphorisms that Trouble Common Sense are texts that work through ambiguity, apparent contradiction or paradox. They make some intellectual demands, which is part of their appeal. They act by troubling normal logic, with an ambiguity that allows for the overlapping of different interpretations or by offering a contradiction that gives a glimpse of a paradox. If successful, these types of texts can compel the reader to re-think and produce an interpretation that makes sense out of apparent nonsense. It should be noted that techniques to produce the opening effect do not exclude each other and overlap in some texts; thus, many of the following seven types of aphorisms could be allocated fairly in different categories.

(1) A veces creo en la eternidad. Pero sólo por un instante. Sometimes I believe in eternity, but only for an instant. 
(2) Cuán pobre hubiera sido, si no tuviera esta miseria.

How poor I would have been, if I did not have this misery.

(3) En el invierno, los amores maduros reverdecen.

In wintertime, mature loves turn green again.

(4) Hay encuentros que buscamos sólo para perdernos.

Some encounters we seek only to lose ourselves in.

(5) De mi corazón se fueron los fantasmas. Ahora el silencio es aterrador.

The ghosts have gone from my heart. Now, the silence is terrifying.

(6) Para no sacrificar a nadie hay que estar dispuesto al sacrificio.

To avoid sacrificing anyone, one has to be ready to sacrifice oneself.

In text (1), the contradictory idea of an eternity that lasts only an instant is an interpretation that arises when one reads the second part of this text as a clause referring to the object. If the clause is read as referring to the action, the text becomes a confessional one. The second text also has a confessional tone and invites the reader to find a meaning for the words 'poor' and 'misery' that overcomes the paradox of the text. Text (3) does not have a confessional colouring, but introduces a situation in which certain senses, usually in opposition (the quality of being "mature" and the idea "to become green again"), seem to hold a relation of cause and effect. Text (4) is a word game in which readers should make sense of a situation that, paradoxically, portrays a necessity that a particular action usually tries to fulfil as its intended consequence; i.e., the result of a search (the encounter) is to be lost. Text (5) works like text (4), as a word game between 'ghosts' and 'terrifying', but the contradiction arises only when it is seen in the light of a confessional tone. Text (6) can be seen as a maxim that contradicts its own absoluteness.

4.2. II) Aphorisms that Hint at a Character are texts that provide a feature that may allow the reader not only to complete a possible character but, in the best cases, to "narrativize" the text. Hinting at a character 
is a difficult technique in which, at its best, the feature provided has to be suggestive enough to compel the reader to picture a character by asking questions about the identity of the person the text is possibly referring to -about his actions and motivations, and so on. Thus, the character might also suggest its own natural environment and the problems probably related to such an environment. In many cases, a cultural reference is crucial to the completion of the sense of this type of text.

(1) Ese tipo de hombres que cuando se refugian en sí mismos están a la intemperie...

The type of people who, by taking refuge in themselves, are at mercy of the elements... ${ }^{8}$

(2) Confunde su miedo con el amor. Eso le protege.

He confuses his fear with love. That protects him.

(3) Inventaba enemigos formidables. Lo mejor de su vida eran sus enemigos.

He invented formidable enemies. The best thing in his life was his enemies.

(4) Se lapidaban con piedras filosofales.

They stoned each other with philosopher's stones.

(5) Amaba ir al desierto a rescatar predicadores.

He loved rescuing preachers from the desert. ${ }^{9}$

(6) Aquellos que sólo fueron provincianos de su propia pena...

Those who were merely provincial in their own sorrows...

8 The Spanish expression a la intemperie can be translated as at mercy of the elements or as out in the open, but it also has connotations of being without protection, homeless, hopeless and defenceless. Unfortunately, the shade of these last meanings has been blurred in this translation.

9 There is a Spanish saying predicar en el desierto [preaching in the desert]; its standard interpretation could be something like talking to people who do not want to listen. 
On the one hand, texts (1) and (6) could suggest the existence of a pattern of grammatical incompleteness, which is useful for the aphoristic opening effect. On the other, texts (2), (3) (4) and (5) provide a complement without an explicit noun (see Spanish original). Texts (4) and (5) rely strongly on cultural references: a widely known one, such as philosopher's stones, and a popular one, such as the Spanish saying "preaching in the desert." Text (2) and (3) could also come under the category of Aphorisms that Trouble Common Sense.

All these texts first attempt to invite the question "who" and, also, the question 'why' and make the reader feel the freedom of playing with different possible answers (a statement which should be taken cautiously when one remembers Heidegger's idea that "the form of the question suggests the answer"). The presentation of possibilities may lead the reader to imagine and animate a character.

4.3. III) Confessional Aphorisms are texts that show intimate and/or hidden details of a human character. By using "I" or "We"as a point of view and/or touching on issues related to the human condition, these kinds of text can build a sense of sharing or identification between the reader and the authorial character. The emotional appeal of most of these confessional texts does not rely on the sharing of guilt, revulsion or horror, because they do not target a sense of shame, taboo or voyeurism. They do not aim to produce discomfort with one's self or one's own life, neither do they intend to make fun through self-deprecation. I think confessional aphorisms can lower the reader's defences through empathy or identification; they can destabilize his own selfimage through recognition of its defective aspects. My hypothesis is that this opening effect depends on suggesting a new balance to the reader in which flaws are accepted as a fundamental part of the whole self.

(1) Mi miseria es pequeñita. Creo que es por eso que me siento tan miserable.

My misery is so tiny. I think that is why I feel so miserable.

(2) Si no fuera yo tan pequeño, estaría sin defensa.

If I weren't so small, I would be defenceless. 
(3) Los dientes que pierdo con el tiempo... muerden los años. The teeth I lose over time... the sharp teeth of passing years.

(4) Todo aquello que no he sido y que ha sido lo mejor de mí... Everything that I have not been and that has been the best of me...

(5) Se da la vida poco a poco, por cosas que no valen mucho, pero que al final siempre valdrán una vida. Life is given little by little for things that aren't worth much, but in the end, they are always worth a life. ${ }^{10}$

(6) En esta tarde me he puesto a buscar el sentido de la existencia, luego he buscado el sentido de la reflexión. Y descubrí por fin que eché a perder el sentido de la tarde.

This afternoon, I began to look for the meaning of life, then for the meaning of reflection. What I finally discovered was that I had squandered the meaning of the afternoon.

All confessional aphorisms might hint at an authorial character, and texts (1), (2), (4) and (5) could also be allocated under the heading of Aphorisms that Trouble Common Sense. Text (5) presents the characteristic of having an undetermined personal pronoun; however, its generality implies an application to any of us. All these texts are confessions of fear, fragility, failure or acknowledgement of a weakness (or wickedness). They do not attempt to make human flaws a target of irony. Rather, through a humorous or acceptant attitude, they try to include such flaws as part of what it is to be human.

4.4. IV) Metaphorical Aphorisms are texts that rely on images to offer clues for a meaningful interpretation. Meaning is not presented with the certainty of a statement, nor as an apparent conclusion. This technique attempts to allow readers to grasp meaning through an image when searching for sense.

10 The meaning of valer is ambiguous in Spanish - it could mean to be worth or/and to cost. In English, there is no such ambiguity. The final line could be translated as: they always cost a life. 
(1) Por culpa de sus alas el zopilote no puede salir de su laberinto. Because of its wings, the vulture can't get out of the labyrinth.

(2) La paciencia ante la amargura, la sed... En el desierto nacen flores, frutos dulcísimos...

Patience in the face of bitterness, thirst... In the desert are born flowers and the sweetest fruits...11

(3) La muerte nos acaricia, en nuestras arrugas se observa su huella digital.

Death caresses us, its fingerprints are seen in our wrinkles.

(4) Ninguna flor sobrevive dos primaveras.

No flower survives two springs.

(5) Hay que subirse a la cruz para tener la cabeza más alta que los demás. To hold one's head higher than all others, one must climb the cross.

I like text (1), but the image has to be explained: the vulture mentioned in the Spanish text is a Zopilote -a type of Mexican vulture that is well known for its habit of scanning immense territories with elegant, concentric and seemingly contemplative flight. This text also could be allocated to the category of Aphorisms that Trouble Common Sense by suggesting an opposition between wings

11 In this Spanish text, there are intended grammatical 'incorrections' that slow down the pace of reading. In the first part of the text, there is a complex noun without a verb ( $\mathrm{La}$ paciencia ante la amargura [Patience in the face of bitterness]) followed by a noun after a coma (la sed [ thirst]). In Spanish, with the article La, paciencia ante la amargura becomes a complex noun, not a piece of advice nor an imperative suggestion to be patient, as it is without the article; thus, in this aphorism, there is no indication of an action, only the mention of a certain thing or state. The next noun la sed [ thirst] is not part of a new sentence, but a kind of complement, which echoes the previous complex noun. The attempt is to provide a feature from which the reader can generate thoughts related to an emotional state, preparing him or her for the second part of the text. It should also be noted that, in Spanish, a sequence in which the last element is not preceded by the conjunction $y$ [and] means that the sequence probably continues: En el desierto nacen flores, frutos dulcísimos... [In the desert, flowers are born and the sweetest fruits...]. 
and freedom -or even to the category of Aphorisms that Hint at a Character. However, the need to think it visually in order to make sense of it encouraged me to place it here. Texts (3), (4) and (5) do not seem to present the same complication. However, it is remarkable that text (2) revealed itself as being both cryptic for many readers and very suggestive for many fellow poets.

4.5. V) Aphorisms that Tease a Commonplace are texts that achieve their effect by playing with well-established opinions or stereotypes. The use this kind of text can make of the commonplace is diverse; for instance, by contradicting the way of thinking suggested by the commonplace or by using it as an advantageous standpoint.

(1) - Los perros ladran, Sancho. Eso indica que nos movemos.

- No, señor, indica que ladran.

- The dogs are barking, Sancho. That means we are advancing.

- No, Sir, it means they are barking. ${ }^{12}$

(2) Cruzar un puente. Estar junto a alguien. Y darse cuenta de que lo único que nos había unido era el puente.

To cross a bridge. To be with someone. And to realise the only thing that united us was the bridge.

(3) A diferencia de los grandes pueblos de la Antigüedad, por circunstancias climáticas, los ingleses están negados para el pensamiento contemplativo sobre el cielo y la armonía de sus sistemas. De ahí su pedestre sentido práctico: quien no puede perderse en las alturas sólo se interesa en controlar sus pasos.

Unlike the great people of Antiquity, the English, for climatic reasons, have no gift for contemplative thought about the sky and the harmony of its systems. That explains their pedestrian

12 This text is a re-elaboration of a very popular and apocryphal quote from El Quijote de la Mancha by Cervantes. Such a phrase is frequently used as an optimistic and/or arrogant response to criticisms and obstacles. 
practical sense: those who cannot get lost in the heights are only interested in controlling their feet.

(4) Sólo un corazón cargado de riquezas puede darse por nada.

Only a heart loaded with riches can be given away for nothing.

(5) No todo infierno purifica.

Not all the fires of purgatory purify.

(6) ¿No es natural que miles de ratones sueñen con que les crecerán alas?

Is it not natural that thousands of mice dream of growing wings?

Text (1) playfully contradicts the commonplace - at least in Spanish speaking countries- of movement as equal to progress. Because of its intimate nature, text (2) could suggest a confessional tone or the hint of a character; however, it can be argued that the crucial element in this text's building of effect is the common idea of a bridge as a union. Text (3) plays with a commonplace and a stereotype: the English weather and English common sense. Text (4) profits from the commonplace of the generosity of golden hearts, adding the playful idea of a richness that can be given away for free (which could allow us to classify it, as well, under Aphorisms that Trouble Common Sense). Text (5) could be seen as the mere negation of a commonplace. Text (6) works on a common opinion deeply established in the linguistic roots of some Latin languages, such as Spanish (see the note on the translation).

4.6. VI) Aphorisms that Hint at Questions are texts generally presented as blatant statements that do not seem to make sense, compelling the reader to find a reference to interpret the text. Usually, such a reference comes in answer to the questions Why, Which, Who, What for or/and What. By leading readers to fill the role of fitting the aphorism to a frame of reference (found through the application of a question), this technique appears to open completion of the text to the reader's participation. 
(1) Uno de los refinamientos más delicados del infierno es hacer que el alma piense en el paraíso.

Proverbio Persa

One of the most delicate refinements of Hell is to remind the soul of Paradise.

Persian Proverb

(2) Sólo el infierno prueba la existencia del alma.

Only Hell proves the existence of the soul.

(3) Tan satisfecho está de los demás que nadie debiera perdonarle. So satisfied is he with all others that no one should forgive him.

(4) Ved los corazones: algunos conocen el arte del zurcido invisible. Look at hearts: some know the art of invisible mending.

(5) Hay pequeñas cosas por las que estaríamos dispuestos a morir, si fuéramos tan grandes como para vivir a su medida.

There are small things for which we would be ready to die, if only we were noble enough to live at that level. ${ }^{13}$

Although text (3) invites us to ask the question who, it principally points more to human relations than to a character itself. Texts (1), (2) and (4) primarily invite the question why. Text (5) relates to the question which, and it could also be allocated to the category of Confessional Aphorisms.

4.7. VII) Aphorisms that Tease Out Cultural Assumptions are texts that trigger associations between the text and meaningful domains of our cultural tradition to produce their effect. Usually, those domains are explicitly signalled by the mention of a canonical reference; such

13 I have translated grande as noble - which is totally correct; however, this English version has lost the game of contrasting pequeñas cosas (small things) with our own size (si fuéramos tan grandes - grande means also big). 
a reference indicates the appropriate context for the text. To provide a meaningful reference for the text, readers have to use their knowledge of context; such an operation can open them to the context's complexity of meaning in relation to the textual sense. It is no surprise that canonical references are recurrent in these texts: they are generally associated with domains that have become very significant in our cultural tradition.

(1) Dante creó una lengua para escribir su poema. Ello refiere la pretensión esencial de alcanzar altura: en el arte verdadero todo es Babel.

Dante created a language to write his poem. This reveals the essential aspiration to achieve lofty heights. In true art, all is Babel.

(2) Al final de su periplo Colón se descubrió a sí mismo utilizado, viejo y solo: "El destino más triste de un hombre es llegar a ser un tonto por lo que sueña".

At the end of his journey, Columbus found himself used, old and alone. "The saddest fate of a man is to become a fool because of his dreams."

(3) Ser como los griegos. Que sólo fragmentos de nuestras obras, los que permitan adivinar alguna magnificencia en el conjunto, lleguen hasta los demás.

To be like the Greeks. Only fragments of our works reach them, those which allow others to suspect a certain magnificence in the entirety of it.

(4) Hay bocas en las que Nietzsche suena como un cencerro.

There are mouths in which Nietzsche sounds like a cowbell.

(5) Cada risa es un modo de hablar. La alegría es Babel, puebla al mundo con nuevos tonos, con bocas nuevas, con nuevas lenguas, sugerencias del cielo pequeñito de los otros: cada idioma inicia como una manera de querer morar en el paraíso. 
Each laugh is a way of speaking. Joy is Babel, populating the world with new tones, with new mouths, with new tongues, suggestions from the small heaven of others: each language initiates something like a way of wanting to inhabit paradise.

(6) Antes de Platón se contaba el mito de una caverna en el que un hombre, el que había logrado salir, soñaba con no haberlo hecho. Before Plato, the myth was told of a cave in which a man, who had managed to leave, dreamed of not having done so.

Given that the references for Aphorisms that Tease Out Cultural Assumptions are a kind of canonical commonplace, it may be difficult to differentiate this type of text from Aphorisms that Tease a Commonplace. If Confessional Aphorisms are a sub-type of Aphorisms that Hint at a Character, where the main distinguishing feature is the use of the pronouns "I" and "We," the criterion for distinction between Aphorisms that Tease a Commonplace and Texts of Cultural Tease Out Cultural Assumptions is not so clear. Such a criterion could be reduced to the difference between audiences that hold common knowledge or opinions, and to the importance of the commonplace in the construction of the text -both very relative standards. ${ }^{14}$

\section{Conclusions and Final Thoughts}

In speculating on the aftertaste of certain aphorisms, I have proposed a distinction between aphorisms with a closure effect and aphorisms with an opening effect. The question that interests me is how these reading effects are produced and what aphoristic techniques may be employed. Judging by the lack of aphorists and aphorisms, the answer might be difficult to find. I do not think it would be wise to attempt to make up

14 Addressing the circumstantial character of a canonical status, Northrop Frye wrote in The Mythos of Summer: Romance:

Most cultures regard certain stories with more reverence than others, either because they are thought of as historically true or because they have come to bear a heavier weight of conceptual meaning. (1975: 101) 
recipes for the writing of the genre. Instead, what I have done here is to offer a personal perspective on some attempts at producing certain kinds of texts with an opening effect. My technical speculation obviously draws on my own theoretical attempt to understand certain types of aphorisms from the perspective of a communicative system in which texts are thought of as access devices that can be implemented by readers to tease out meaning from their cultural context (see Angel-Lara, 2011). If this is so, there are certain implications that are worth mentioning:

a) From this perspective, these types of aphorisms do not appear as short or simply unfinished versions of poems, plays, arguments, stories or essays. In a certain sense, aphorisms with opening and closure effects may be better thought of as a kind of written remark on the cultural context (see Angel-Lara, 2011). To a certain extent, they are secondary texts, with their references $(i . e$., a myth, a common place, a saying, a belief of any kind, another written text, etc.) being the primary text.

b) The canonical importance of the primary texts is not in direct relation to the value of aphoristic texts. Not all aphorisms on canonical topics will be good texts. As in any other genre, the artistic craft is what makes the difference.

c) In general, the aphoristic making of texts that produce the disproportion effect involves lots of second guessing in their interpretation process. Specifically, in making texts with an opening effect, part of this guessing is invested in the trick of gently destabilizing the interior order of a reader's frame of mind (to produce a new balance in which the text plays a part). The necessity of this guessing process in making the texts may explain the "writing laziness" from which aphorists, such as Cioran and Don Paterson, claim to suffer. It could be argued that, during the "lazy time" in which they do not write a line, aphorists are not only designing the text, but also feeling the thinking in which the text is going to be incorporated. ${ }^{15}$

15 Fenton suspected something like this when he wrote:

It may be that an aphorism is the product of much hard work, that it is tried out and revised, honed in the notebooks before being shown (if ever) to the public. (Fenton, 2007: 15) 
d) It may also be clear that providing clues to suggest a path of thinking involves not only assuming a shared reference with the reader, but also, in general, similar mental and emotional processes. The aphorist relies on that and, also, on the collusion of readers who do not expect aphorisms to reveal their significance themselves, but only to provide a few clues they can work with.

\section{References}

Ángel-Lara, Marco A. (2013). "Some Aphoristic Reading Effects: The Experience of an Apparent Disproportion between Textual Size and Meaning." In Pensamiento y Cultura, v. 16, no. 2 (2013: 122-43).

Ángel-Lara, Marco A. (2012). "Excerpts from The Lectern of a Firefly." The Brooklyn Rail (In Translation), http://intranslation.brooklynrail. org/spanish/excerpts-from-the-lectern-of-a-firefly.

Ángel-Lara, Marco A. (2011b). "Aphorisms and Philosophy: Contextualizing Aphoristic Texts - Assumptions about Subject-Matter." In Journal of English Studies, no. 9: 29-54.

Ángel-Lara, Marco A. (2011a). El atril de la luciérnaga, Guadalajara, México: Arlequín.

Auden, W. H. and L. Kronenberger (1964). The Faber Book of Aphorisms: A Personal Selection. London: Faber and Faber.

Dalrymple, T. (2001). "Discovering La Rochefoucauld." In The New Criterion Online, 19: 8, April. http://www.newcriterion.com/archive/19/ apr01/laroche.htm [accessed 12/ Feb/ 2008]

Derrida , Jacques (1992). “Aphorism Countertime.” In Derek Attridge (Editor). Jacques Derrida: Acts of Literature. London: Routledge: 414- 33.

Fadiman. Clifton (1962). "Introduction." In Lec, S. Jerzy. Unkempt Thoughts. New York: St. Martin’s Press.

Fenton, James (2007). “On the Difficult Art of the Aphorism." Guardian 17.02.2007 2007, sec. Review: 15.

Fruchtl, Josef (1997). “The Aphorism as a Stylistic and Epistemological Ideal: Theodor W. Adorno and Botho Straus.” REAL 13: 161-73. 
Frye, Northrop (1957) “The Mythos of Summer: Romance." In Duff, David (2000). Modern Genre Theory.98-117, London: Longman.

Geary, James (2005). The World in a Phrase: A Brief History of the Aphorism. 1st U.S. ed. New York: Bloomsbury.

Joubert, Joseph (1983). The Notebooks of Joseph Joubert: A Selection. Tr. by Paul Auster, San Francisco: North Point Press.

La Rochefoucauld, Francois de (2001). Maxims. Tr. by Stuart D. Warner and Stéphane Douard, South Bend, Indiana: St. Augustine's Press.

Lewis, Philip E. (1977). La Rochefoucauld: The Art of Abstraction. London: Cornell University Press.

Lindley, David (1986). Thomas Campion, BRILL, Leiden.

Maddocks, M. (2001). “The Art of Aphorism.” Sewanee Review 109 (2): 171-85.

Marsden, Jill (2006). "Nietzsche and the Art of the Aphorism.” In AnsellPearson, Keith (Ed.) A Companion to Nietzsche, Blackwell, 22-40

Morson, G. S. (2003). “The Aphorism: Fragments from the Breakdown of Reason." New Literary History 34 (3): 409-29.

Morson, G. S. (2006). “The Rhetoric of the Aphorism.” In Walter Jost and Wendy Olmsted (Eds.). A Companion to Rhetoric and Rhetorical Criticism, Oxford: Blackwell.

Narosky, José (1975). Si todos los hombres..., Buenos Aires: Ed. Antártida. .

Pagliaro, Harold E. (1964). "Paradox in the Aphorisms of La Rochefoucauld and Some Representative English Followers." PMLA 79.1: 42-50.

Porchia, Antonio (2003). Voices, Tr. by W. S. Merwin, Port Townsend, Washington: Copper Canyon Press.

Sontag, Susan (1980). Under the Sign of Saturn, New York: Farrar, Straus Giroux.

Stern, Joseph Peter (1963). Lichtenberg: A Doctrine of Scattered Occasions, Reconstructed from His Aphorisms and Reflections. London: Thames \& Hudson. 
Wimsatt, William K. and Monroe C. Beardsley (1988). “The Intentional Fallacy." In Selden, Raman. The Theory of Criticism: From Plato to the Present, London: Longman. pp. 314-16.

Wittgenstein, Ludwig (2001). Philosophical investigations, Oxford: Blackwell.

Wittgenstein, Ludwig (2002). Tractatus Logico-Philosophicus. Trans. C. K. Ogden. London: Routledge. 